\title{
Skeletal muscle water and electrolytes following prolonged dehydrating exercise
}

\author{
R. Mora-Rodríguez, V. E. Fernández-Elías, N. Hamouti, J. F. Ortega
}

Exercise Physiology Laboratory at Toledo, University of Castilla - La Mancha, Toledo, Spain

Corresponding author: Ricardo Mora-Rodríguez, PhD, Exercise Physiology Laboratory at Toledo, University of Castilla - La Mancha, Avda. Carlos III, s/n, 45071 Toledo, Spain. Tel: 925268800 (ext 5510), Fax: 925268846, E-mail: Ricardo.mora@uclm.es

Accepted for publication 4 August 2014

\begin{abstract}
We studied if dehydrating exercise would reduce muscle water $\left(\mathrm{H}_{2} \mathrm{O}_{\text {muscle }}\right)$ and affect muscle electrolyte concentrations. Vastus lateralis muscle biopsies were collected prior, immediately after, and 1 and $4 \mathrm{~h}$ after prolonged dehydrating exercise $\left(150 \mathrm{~min}\right.$ at $33 \pm 1^{\circ} \mathrm{C}, 25 \% \pm 2 \%$ humidity) on nine endurance-trained cyclists $\left(\mathrm{VO}_{2 \max }=\right.$ $54.4 \pm 1.05 \mathrm{~mL} / \mathrm{kg} / \mathrm{min})$. Plasma volume (PV) changes and fluid shifts between compartments $\left(\mathrm{Cl}^{-}\right.$method) were measured. Exercise dehydrated subjects $4.7 \% \pm 0.3 \%$ of body mass by losing $2.75 \pm 0.15 \mathrm{~L}$ of water and reducing PV $18.4 \% \pm 1 \%$ below pre-exercise values $(P<0.05)$. Right after exercise $\mathrm{H}_{2} \mathrm{O}_{\text {muscle }}$ remained at pre-exercise values (i.e., $398 \pm 6 \mathrm{~mL} / 100 \mathrm{~g}$ dw muscle ${ }^{-1}$ ) but declined
\end{abstract}

$13 \% \pm 2 \% \quad\left(342 \pm 12 \mathrm{~mL} / 100 \mathrm{~g}\right.$ dw muscle $\left.^{-1} ; \quad P<0.05\right)$ after $1 \mathrm{~h}$ of supine rest. At that time, PV recovered toward pre-exercise levels. The $\mathrm{Cl}^{-}$method corroborated the shift of fluid between extracellular and intracellular compartments. After $4 \mathrm{~h}$ of recovery, $P V$ returned to preexercise values; however, $\mathrm{H}_{2} \mathrm{O}_{\text {muscle }}$ remained reduced at the same level. Muscle $\mathrm{Na}^{+}$and $\mathrm{K}^{+}$increased $(P<0.05)$ in response to the $\mathrm{H}_{2} \mathrm{O}_{\text {muscle }}$ reductions. Our findings suggest that active skeletal muscle does not show a net loss of $\mathrm{H}_{2} \mathrm{O}$ during prolonged dehydrating exercise. However, during the first hour of recovery $\mathrm{H}_{2} \mathrm{O}_{\text {muscle }}$ decreases seemly to restore PV and thus cardiovascular stability.
During prolonged exercise in the heat, subjects lose large amounts of fluid by sweating. However, the contribution of each body fluid compartment (intracellular, extracellular, and vascular) to sweat loss is not well defined. With the transition from rest to exercise, plasma volume (PV) rapidly declines by $\sim 8 \%$ and from there, there is a progressive loss of $\mathrm{PV}$ to around $13 \%$ when exercise lasts $120 \mathrm{~min}$ (i.e., $450 \mathrm{~mL}$ loss; Costill et al., 1976). However, PV accounts for a small percentage of all the fluid losses that take place during prolonged exercise. Necessarily, fluid from the interstitial and intracellular fluid (ICF) spaces ought to be contributing to water loss during prolonged exercise. However, it is unclear to what extent water from active muscles contributes to the sweat losses during or after prolonged dehydrating exercise. Water has an important metabolic role in contracting muscle and its deficit could trigger catabolic responses (Häussinger, 1996) and have negative consequences in $\mathrm{pH}$ regulation and gene expression (Schäfer et al., 2007).

Costill and associates studied muscle water changes during (Costill et al., 1981) and after prolonged dehydrating exercise (Costill et al., 1976) in active and inactive muscles. They obtained muscle biopsies and carefully measured the loss of tissue weight after thorough drying using high temperature. They found that if biopsies are obtained during exercise, active muscle does not decrease but rather increases its water content (Costill, 1977). Sjøgaard and Saltin (1982) also reported increases in active muscle water when sampling muscle right after three bouts of supramaximal cycling exercise. Likewise, increases in muscle water have also been reported after intense knee extension exercise (Sjøgaard et al., 1985; Ploutz-Snyder et al., 1995; Kristiansen et al., 2014).

However, when exercise is prolonged, Costill et al. (1976) were able to measure progressive reductions in muscle water that reached $7 \%$ when body weight decreased $5.8 \%$ by dehydration. Surprisingly, in a follow-up study, Costill et al. (1981) reported no changes in total muscle water content after a $3.2 \%$ reduction in body weight by exercise inducing sweating. They speculated that the muscle water loss could have been compensated by the water released from the breakdown of glycogen, water formed during oxidative phosphorylation, or water drawn from the gut. In this study, muscle biopsies were taken $30 \mathrm{~min}$ after exercise discontinuation. It is also possible that $30 \mathrm{~min}$ was insufficient time to allow fluid to shift from muscle to the vasculature, explaining the unchanged muscle water content after $3.2 \%$ whole-body dehydration.

Neufer et al. (1991) reported an $8 \%$ reduction in active muscle water after $4.8 \%$ whole-body dehydration by exercise. With similar degree of dehydration, Hackney 


\section{Mora-Rodríguez et al.}

et al. (2012) report only 5\% reduction in knee extensor water content [measured by magnetic resonance imaging (MRI)]. The exercise intensity was higher in the Neufer et al. study and the sampling time also differed between studies. It is possible that the time elapsed between ending the exercise and biopsy (or MRI) sampling plays a role in the muscle water deficit results obtained. After exercise, hydrostatic pressure rapidly declines to resting values allowing muscle water to shift to other fluid spaces replenishing their fluid losses. Lastly, the role of muscle electrolytes on preserving or allowing muscle water losses is undetermined.

In the present study, we examine the changes in water and electrolyte contents of active muscle after large sweat losses induced by prolonged exercise in the heat. Our hypothesis is that during recovery from dehydrating exercise, water shifts from muscle to the extracellular fluid (ECF) space to help in the recovery of PV. Although indirect measures (i.e., $\mathrm{Cl}^{-}$method) suggest that fluid shifts occur after exercise to replenish PV (Nose et al., 1988; Sanders et al., 1999; Hamouti et al., 2013), the specific role of muscle water on this recovery is unclear. To test our hypothesis, we sampled and analyzed muscle water and electrolyte contents before, right after exercise, and after 1 and $4 \mathrm{~h}$ of recovery. This should allow us to describe the timing and participation of muscle water in post-exercise fluid and electrolyte shifts among compartments.

\section{Methods}

\section{Participants}

Nine endurance-trained male cyclists, who routinely cycled at least $2 \mathrm{~h}$ /day, 4-7 days/week during the last 3 years, participated in the study. Participants were $24 \pm 9$ years old, weighed $69 \pm 7 \mathrm{~kg}$, and their height and percent body fat [dual-energy X-ray absorptiometry (DXA) evaluated] were of $1.73 \pm 7.1 \mathrm{~m}$, and $14.8 \% \pm 1.7 \%$, respectively [all mean \pm standard deviation (SD)] Their $\mathrm{VO}_{2 \max }$ was of $54.4 \pm 3.1 \mathrm{~mL} / \mathrm{kg} / \mathrm{min}$. Subjects were fully informed about the experimental procedures and the possible risks and discomforts associated with the experiment before they gave their written informed consent to participate. The study was approved by the Virgen de la Salud Hospital Research Ethics Committee in accordance with the latest version of the Declaration of Helsinki.

\section{Preliminary testing}

In their first visit to the laboratory, participants underwent a physical examination including rest and exercise electrocardiogram (Cosmed T12, Rome, Italy). They performed an incremental cycling test to volitional fatigue using an electromagnetically braked cycle ergometer (Cardiotest 100, Seca, Hamburg, Germany) to determine their maximal aerobic power $\left(\mathrm{VO}_{2 \max }\right)$. After a 5-min warm-up at $100 \mathrm{~W}$, participants began cycling at $125 \mathrm{~W}$ with increments of $25 \mathrm{~W}$ each minute. Gas exchange data were collected using an automated breath-by-breath system (Quark b2, Cosmed) and averaged every $15 \mathrm{~s}$. $\mathrm{VO}_{2 \max }$ was defined as the highest plateau (two successive maximal readings within $0.15 \mathrm{~L} / \mathrm{min}$ ) reached. Percent body fat and legs lean soft-tissue mass were determined by DXA (DXA Hologic Series Discovery Wi QDR, Bedford, Massachusetts, USA). Regional analysis of leg soft-tissue mass included the gluteal and psoas muscles by analyzing scans from the iliac crest to the foot.

\section{Experimental protocol}

Participants refrained from exercising the day before the trials and performed a standardized low-intensity workout $48 \mathrm{~h}$ before the trial. Subjects were instructed to follow a diet rich in carbohydrates $(5-8 \mathrm{~g} / \mathrm{kg} / \mathrm{day})$ and drink liberally in the $24 \mathrm{~h}$ before the trial. Upon awakening, $1 \mathrm{~h}$ before arriving to the laboratory, participants were required to eat a standardized breakfast [i.e., $330 \mathrm{~mL}$ of a fruit milkshake (168 kcals) and a pastry (456 kcals)] and drink $500 \mathrm{~mL}$ of water to promote euhydration. Upon arrival to the laboratory, subjects voided and their nude body weight was measured using a \pm 0.05 sensitive scale (Seca 764). A urine sample was analyzed for specific gravity (Usg) using a hand-held refractometer (Master-Sur/No, Atago, Tokyo, Japan) to confirm euhydration (i.e., < 1.020; Sawka et al., 2007). If subject's Usg was above 1.020, the trial was aborted and the subject was re-scheduled. Then, subjects lay down on a stretcher and were catheterized (20-gauge Teflon ${ }^{\circledR}$; BD Insyte, Becton Dickinson, Madrid, Spain) in an antecubital vein. The catheter was kept patent by frequent flushing with $1 \mathrm{~mL}$ of $0.9 \%$ sterile saline (Grifols, Barcelona, Spain). After $20 \mathrm{~min}$, a muscle biopsy was obtained from the vastus lateralis and a blood sample drawn to be used as baseline for PV changes calculations.

Immediately after, participants dressed up in shorts and cleated cycling shoes, and entered in the climatic chamber, set at $33 \pm 1{ }^{\circ} \mathrm{C}$ with $25 \% \pm 2 \%$ relative humidity (mean $\pm \mathrm{SD}$ ) and $2.5 \mathrm{~m} / \mathrm{s}$ wind speed, where they sat quietly on the cycle ergometer for $15 \mathrm{~min}$. A heart rate monitor was positioned around their chest (RS400, Polar, Kempele, Finland) to record heart rate during exercise. Then, a pre-exercise blood sample was drawn (time 0 in Fig. 1) and subjects started pedaling at $65 \% \mathrm{VO}_{2 \max }$ during $120 \mathrm{~min}$ followed by 30 more minutes at $55 \% \mathrm{VO}_{2 \max }$ to complete $150 \mathrm{~min}$ of exercise. During exercise blood samples were collected at 15, 60, 120, and $150 \mathrm{~min}$ of exercise. Customized adhesive non-allergenic sweat patches $\left(10 \times 12 \mathrm{~cm}\right.$, Tegaderm ${ }^{\mathrm{TM}}+\mathrm{Pad}, 3 \mathrm{M}$, St. Paul, Minnesota, USA) were placed in the middle back after cleaning the skin with deionized water as previously described (Hamouti et al., 2011) and collected after $30 \mathrm{~min}$ of sweat collection at 60 , 120 , and $150 \mathrm{~min}$ of exercise. At these time points nude body weights were also measured to calculate sweat rate. $\mathrm{VO}_{2}$ and $\mathrm{VCO}_{2}$ were measured using indirect calorimetry for 3 min after $15,55,115$, and $145 \mathrm{~min}$ of exercise. Upon completion of the dehydrating exercise, the last sweat patch and the heart rate chest band were removed and participants exited the hot chamber. Subjects moved to a stretcher and then a second muscle biopsy sample was obtained (immediately post). Participants' toweled-dry before post-exercise nude body weight was collected and then subjects voided when possible. Participants remained on the stretcher for $4 \mathrm{~h}$, whereas blood samples, muscle biopsies, and body weight were obtained 1 and $4 \mathrm{~h}$ post-exercise. In an attempt to maintain the same level of dehydration and knowing that during the $3 \mathrm{~h}$ of rest water will be loss by sweating and breathing and urine will be formed, we provided subjects with $330 \mathrm{~mL}$ of water right after the 1-h biopsy. Urine was collected at any time during the resting period that the subjects could urinate. Once the trial concluded, participants were provided with food and drink, and instructions to take care of the biopsy wounds.

\section{Body water balance}

Urine volume during the trial was measured with a graduated cylinder (Simax $1000 \mathrm{~mL}$, Prague, Czech Republic) and $1.5 \mathrm{~mL}$ of aliquots stored at $-80{ }^{\circ} \mathrm{C}$ until analysis. Sweat volume was calculated from the losses of body weight subtracting respiratory and 
Fluid losses in exercising skeletal muscle

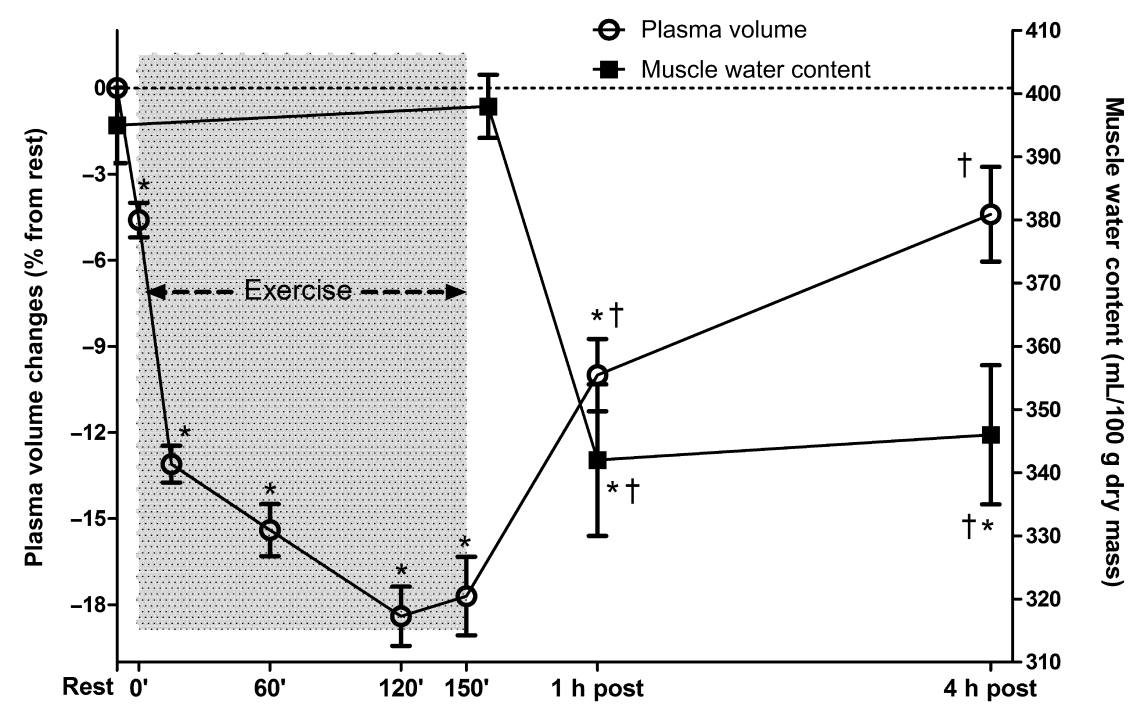

Fig. 1. Changes in plasma volume and muscle water $\left(\mathrm{H}_{2} \mathrm{O}_{\text {muscle }}\right)$ during $150 \mathrm{~min}$ of dehydrating exercise and subsequent 4-h recovery. Data are means \pm standard error of the mean for nine endurance-trained subjects. *Significantly different from rest values. $\dagger$ Significantly different than 150 min end of exercise $(P<0.05)$.

metabolic weight losses. Respiratory water loss (i.e., $m_{\mathrm{e}}$ ) and weight loss associated with excess $\mathrm{CO}_{2}$ expired (i.e., $m_{\mathrm{r}}$ ) were estimated according to the following equations (Mitchell et al., 1972):

$$
\begin{aligned}
& m_{\mathrm{e}}(\mathrm{g})=0.019 \times \mathrm{VO}_{2} \times(44-\mathrm{Pa}) \times \text { exercise time }(\mathrm{min}) \\
& m_{\mathrm{r}}(\mathrm{g})=\mathrm{VO}_{2} \times \mathrm{R} \times\left(\mathrm{\rho CO}_{2}-\rho \mathrm{O}_{2}\right) \times \text { exercise time }(\mathrm{min})
\end{aligned}
$$

where $m_{\mathrm{e}}$ is evaporative water loss from the respiratory tract, $\mathrm{VO}_{2}$ is oxygen uptake in $\mathrm{L} / \mathrm{min}$ at standard temperature pressure dry air (STPD), and $\mathrm{Pa}$ is the ambient vapor water pressure in $\mathrm{mmHg}$ (i.e., $9.77 \mathrm{mmHg}$ in our hot environment). $m_{\mathrm{r}}$ is the metabolic weight loss, $R$ is the respiratory exchange ratio $\left(\mathrm{VCO}_{2} / \mathrm{VO}_{2}\right)$, and $\rho \mathrm{CO}_{2}$ and $\mathrm{\rho O}_{2}$ are the densities of carbon dioxide (1.96 g/L STPD) and oxygen (1.43 g/L STPD), respectively.

Metabolic water formation during exercise was calculated from substrate oxidation. Substrate oxidation rates (fat and carbohydrate) were calculated from non-protein RQ measured by indirect calorimetry (Jeukendrup \& Wallis, 2005) after 15, 55, 115, and $145 \mathrm{~min}$ of exercise. It was assumed that the oxidation of $1 \mathrm{~g}$ of glucose results in the formation of $0.6 \mathrm{~g}$ of water and the oxidation of $1 \mathrm{~g}$ of fat in the formation of $1.13 \mathrm{~g}$ of water (Maughan et al., 2007).

\section{Urine, blood, and sweat analysis}

Blood samples were immediately analyzed for hemoglobin concentration (ABL-520, Radiometer, Brønshøj, Denmark) and hematocrit by microcentrifugation (Biocen, Alresa, Madrid, Spain) in triplicate. Relative changes in $\mathrm{PV}(\Delta \mathrm{PV})$ were calculated with the equations outlined by Dill and Costill (1974). Based on subjects' pre-exercise body mass, PV was calculated following Sawka et al. (1992):

$$
P V(\mathrm{~mL})=[(0.026 \times \text { body mass in } \mathrm{kg})+1.239] \times 1000
$$

Absolute changes in PV (in mL) were calculated from this baseline calculation.

Sweat collected in the patches was separated by centrifugation in sealed tubes and stored at $-80{ }^{\circ} \mathrm{C}$ until analysis. Urine and sweat samples were thawed to room temperature and analyzed for $\mathrm{Na}^{+}$, $\mathrm{K}^{+}$, and $\mathrm{Cl}^{-}$concentrations using an ion-selective analyzer
(Easylyte Plus, Medica Corporation, Bedford, Massachusetts, USA). Blood samples were allowed to clot in serum tubes (Z Serum Sep Clot Activator Vacuette ${ }^{\circledR}$, Greiner Bio-One GmbH, Kremsmünster, Austria) and followed by centrifugation at $4000 \mathrm{rpm}$ for $10 \mathrm{~min}$ at a temperature of $4{ }^{\circ} \mathrm{C}$ (MPW-350R, Med. Instruments, Warsaw, Poland) to obtain serum that was stored at $-80{ }^{\circ} \mathrm{C}$. Serum was analyzed for $\mathrm{Na}^{+}, \mathrm{K}^{+}$, and $\mathrm{Cl}^{-}$concentrations using an ion-selective analyzer (Easylyte Plus, Medica Corporation). $\mathrm{Cl}^{-}$concentration from sweat patches was extrapolated to whole body concentrations according to Patterson et al. (2000) using the specific equation for lower back sweat collection. Serum protein was analyzed using the refractive index in a hand-held refractometer (Master-Sur/N $\alpha$, Atago). Percent change in the concentration and content of serum constituents was calculated from pre-exercise values of corrected hematocrit and solute concentrations according to the equation proposed by van Beaumont et al. (1973).

\section{ECF and ICF shift}

We determined extra- and intracellular water after 60, 120, and $150 \mathrm{~min}$ of exercise as well as 1 and $4 \mathrm{~h}$ into recovery. This determination was based on the chloride method (Costill et al., 1976). Changes in body water loss were estimated from body mass loss. Chloride losses were calculated by multiplying the volume of urine and sweat excreted by the respective concentrations $\left(\left[\mathrm{Cl}^{-}\right]\right.$urine, $\left.\left[\mathrm{Cl}^{-}\right]_{\text {sweat }}\right)$. Changes in interstitial fluid, ECF, and ICF were calculated using Donnan factor-specific formulae for exercise conditions (Sanders et al., 2001).

\section{Muscle biopsy}

Muscle biopsy samples were taken from the vastus lateralis using the suction-modified Bergstrom technique (Tarnopolsky et al., 2011). Skin was prepared with povidone-iodine (Betadine, MEDA, Bordeaux, France), followed by injection of $2 \%$ lidocaine without epinephrine (Braun 2\%, Braun Medical, Rubí, Spain). Then, the skin and underlying tissues were surgically opened (scalpel blade number 10, Braun, Tuttlingen, Germany) and muscle tissue obtained using a 4-mm internal diameter Bergstrom biopsy needle. Upon collection, muscle samples were immediately cleaned of 


\section{Mora-Rodríguez et al.}

connective tissue, divided into two pieces, and rapidly frozen in liquid nitrogen for subsequent analysis of water and electrolyte contents. The incision was closed using adhesive strips (Steri-Strip $\left.{ }^{\mathrm{TM}}, 3 \mathrm{M}\right)$ covered with an adhesive dressing pad (Tegaderm $^{\mathrm{TM}}+\mathrm{Pad}, 3 \mathrm{M}$ ) and compressive dressing (IcoVenda, Novico Medica, Barcelona, Spain). All four biopsies were taken from the right leg using one incision for each biopsy. Incisions were spaced $\sim 5 \mathrm{~cm}$ in between and were taken starting in the mid leg and advancing distally (Costill et al., 1988). Two incisions were made before exercise: one to obtain the pre-exercise biopsy and the other to save time in the immediately post-exercise biopsy procedure.

\section{Measurement of muscle water and electrolytes}

All the samples from a given subject were analyzed in the same assay batch. Frozen samples were weighed on an electronic balance with a sensitivity of $0.1 \mu \mathrm{g}$ (XB220A, Precisa, Dietikon, Switzerland). Elapsed time from sample removal from the freezer until weighing was recorded to permit correction for tissue water evaporation. Samples were freeze dried in a thermoelectric freeze dryer (Cryodos-50, Telstar, Madrid, Spain) for $12 \mathrm{~h}$ at $-50{ }^{\circ} \mathrm{C}$ and at a vacuum of 10-2 Torr. In brief, this apparatus freezes the liquid in the sample to $-50{ }^{\circ} \mathrm{C}$ then sublimates it with a potent vacuum pump at a high flux rate $(83 \mathrm{~L} / \mathrm{min})$. Samples were then reweighed in the same precision scale, and the difference in weight (i.e., water) was expressed per $100 \mathrm{~g}$ of dry tissue. Pilot data in our laboratory in fresh pig leg muscle indicated that $\mathrm{H}_{2} \mathrm{O}_{\text {muscle }}$ measurement was highly reproducible (i.e., 6\% CV). Data in one subject who underwent 10 resting biopsies within 8 weeks in a euhydrated state (Usg $<1.020$ and body weight $\pm 0.25 \mathrm{~kg}$ ) confirmed the high reproducibility of this technique in our laboratory in human muscle (i.e., $5 \% \mathrm{CV}$ ).

Segmental body DXA scan permitted calculation of active legs lean soft-tissue mass (i.e., muscle and connective tissue), which contain most of the limb water. Soft-tissue mass DXA analysis focused in the body segment from the iliac crests to the ankles. Combining those measures with the losses of water in muscle from the biopsies, and assuming a uniform loss of water throughout the leg musculature, we estimated leg muscle water losses after exercise as follows:

$$
\begin{aligned}
\text { Legs } \mathrm{H}_{2} \mathrm{O} \text { loss }(\mathrm{L})= & \text { Biopsy } \mathrm{H}_{2} \mathrm{O} \text { loss }(\mathrm{L} / \mathrm{kg} \text { wt muscle }) \\
& \times \text { DXA Legs lean soft tissue }(\mathrm{kg})
\end{aligned}
$$

Muscle electrolytes were measured according to the methods described in Costill et al. (1981). Muscle samples were submerged overnight in petroleum ether to extract neutral fat. Then, the pieces were reweighed to determine fat-free solid (FFS) weight. The dried specimen was subsequently treated with $100 \mu \mathrm{L}$ of $2 \mathrm{~N}$ nitric acid overnight to extract electrolytes. Muscle sodium $\left(\mathrm{Na}^{+}{ }_{\text {muscle }}\right)$ and potassium $\left(\mathrm{K}^{+}\right.$muscle $)$were determined in that extract using flame photometry (Clinical PFP7; Jenway, Stone, UK).

\section{Statistical analysis}

Data are presented as mean \pm standard error of the mean unless otherwise stated. When the Shapiro-Wilk test revealed nonnormally distributed data $(P<0.05)$, we used Friedman's nonparametric statistical test. Normally distributed data were analyzed using one-way analysis of variance with repeated measures. After a significant $F$-value (Greenhouse-Geisser adjustment for sphericity), pairwise differences were identified using Tukey's (honest significant difference) post-hoc procedure for normally distributed data, and Mann-Whitney $U$-test with correction for multiplicity for non-normally distributed data. Level of significant was set at $P<0.05$. Data analysis was performed using SPSS software for windows (v.18, SPSS Inc., Chicago, Illinois, USA).
Table 1. Body water loss and formation and metabolic weight loss during 150 min of dehydrating exercise in a hot environment

\begin{tabular}{ll}
\hline & Liters (\%BW loss) \\
\hline Body weight loss $(\mathrm{kg})$ & $-3.19 \pm 0.16$ \\
Sweat loss $(\mathrm{L})$ & $-2.65 \pm 0.12(-82.9 \%)$ \\
Breath $\mathrm{H}_{2} \mathrm{O}$ loss $(\mathrm{L})$ & $-0.24 \pm 0.01(-7.5 \%)$ \\
Urine void $(\mathrm{L})$ & $-0.13 \pm 0.07(-4.1 \%)$ \\
$\mathrm{CO}_{2}$ loss $(\mathrm{kg})$ & $-0.18 \pm 0.01(-5.5 \%)$ \\
Metabolic $\mathrm{H}_{2} \mathrm{O}$ formation $(\mathrm{L})$ & $+0.27 \pm 0.01$ \\
Total $\mathrm{H}_{2} \mathrm{O}$ loss $(\mathrm{L})$ & $-2.75 \pm 0.15$ \\
$\%$ Body weight loss from $\mathrm{H}_{2} \mathrm{O}$ & $86 \% \pm 1 \%$
\end{tabular}

Data are means \pm standard error of the mean for nine endurance-trained subjects.

\section{Results}

\section{Percent dehydration and sweat rate}

After $150 \mathrm{~min}$ of exercise subjects dehydrated by $4.7 \% \pm 0.3 \%$ of their initial body weight, losing $2.75 \pm 0.15 \mathrm{~L}$ of water by sweating at a rate of $1.06 \pm 0.05 \mathrm{~L} / \mathrm{h}$. Total water lost explained $86 \% \pm 1 \%$ of body weight losses (Table 1) even when metabolic water formation was accounted. Weight losses associated with excess $\mathrm{CO}_{2}$ accounted for another $5 \%$ with a total of $92 \% \pm 1 \%$ of the weight losses accounted in our calculations (Table 1).

\section{PV changes}

The transition from supine rest to standing rest in the cycle-ergometer reduced PV to $-4.6 \% \pm 0.6 \%$. After $15 \mathrm{~min}$ of exercise PV was further reduced to $-13 \% \pm 0.6 \%(0.400 \pm 0.02 \mathrm{~L} ;$ Fig. $1 ; P<0.05)$. The progressive dehydration reduced PV to $-18.4 \% \pm 1 \%$ after 120 min of exercise. That reduction was maintained during the last $30 \mathrm{~min}$ of exercise (i.e., loss of $0.545 \pm 0.04 \mathrm{~L}$ after $150 \mathrm{~min} ; P<0.05$ ). One hour after exercise, PV returned halfway toward the resting initial values $(-10 \% \pm 1 \%$; Fig. 1), although it was still lower than pre-exercise resting values. After $4 \mathrm{~h}$ of supine recovery, PV was fully recovered with values not different from rest $(-4.4 \% \pm 2 \%$; Fig. 1$)$.

\section{Changes in muscle water content}

Prior to exercise vastus lateralis contained $395 \pm 6 \mathrm{~mL}$ of water per each $100 \mathrm{~g} \mathrm{dw}$ muscle ${ }^{-1}$. $\mathrm{H}_{2} \mathrm{O}_{\text {muscle }}$ remained at pre-exercise values immediately after exercise ( $398 \pm 5$; Fig. 1). However, $1 \mathrm{~h}$ after exercise $\mathrm{H}_{2} \mathrm{O}_{\text {muscle }}$ declined by $13 \% \pm 2 \%$ to $342 \pm 12 \mathrm{~mL} / 100 \mathrm{~g} \mathrm{dw}$ muscle $^{-1}$ (Fig. 1; $P<0.05)$. This reduction of $\mathrm{H}_{2} \mathrm{O}_{\text {muscle }}$ was maintained for another $3 \mathrm{~h}$ with levels after $4 \mathrm{~h}$ of exercise of $346 \pm 11 \mathrm{~mL} / 100 \mathrm{~g} \mathrm{dw}$ muscle ${ }^{-1}$ (Fig. $1 ; P<0.05$ ). Leg water loss was calculated combining biopsy vastus lateralis $\mathrm{H}_{2} \mathrm{O}_{\text {muscle }}$ data with legs DXA scan of lean softtissue mass, assuming that this tissue contains most of the leg water. We detected a loss of $-0.529 \pm 0.10 \mathrm{~L}$ of 
Fluid losses in exercising skeletal muscle

Table 2. Water losses from resting values after 150 min of exercise in a hot environment $\left(33 \pm 1^{\circ} \mathrm{C}, 25 \% \pm 2 \%\right.$ humidity)

\begin{tabular}{lccc}
\hline & Immediately post-exercise & $1 \mathrm{~h}$ post-exercise & $4 \mathrm{~h}$ post-exercise \\
\hline Whole-body $\mathrm{H}_{2} \mathrm{O}$ loss $(\mathrm{L})$ & $-2.750 \pm 0.15$ & $-2.750 \pm 0.15$ & $-2.590 \pm 0.12$ \\
Legs $\mathrm{H}_{2} \mathrm{O}$ loss $(\mathrm{L})$ & $0.012 \pm 0.02$ & $-0.529 \pm 0.10^{\star}$ & $-0.476 \pm 0.10^{\star}$ \\
Plasma $\mathrm{H}_{2} \mathrm{O}$ loss $(\mathrm{L})$ & $-0.545 \pm 0.05$ & $-0.307 \pm 0.04^{\star}$ & $-0.132 \pm 0.05^{\star \dagger}$ \\
Legs + plasma $\mathrm{H}_{2} \mathrm{O}$ loss (L) & $-0.533 \pm 0.03$ & $-0.836 \pm 0.12^{*}$ & $-0.608 \pm 0.12^{\dagger}$ \\
$\%$ from whole-body $\mathrm{H}_{2} \mathrm{O}$ loss (\%) & $19 \% \pm 1 \%$ & $30 \% \pm 4 \%$ & $23 \% \pm 2 \%$ \\
\hline
\end{tabular}

Data are divided into whole-body, plasma, and previously active muscle (i.e., both legs). Data are means \pm standard error of the mean for nine endurance-trained subjects.

${ }^{*}$ Significantly different from immediately post-exercise.

†Significantly different from $1 \mathrm{~h}$ post-exercise.

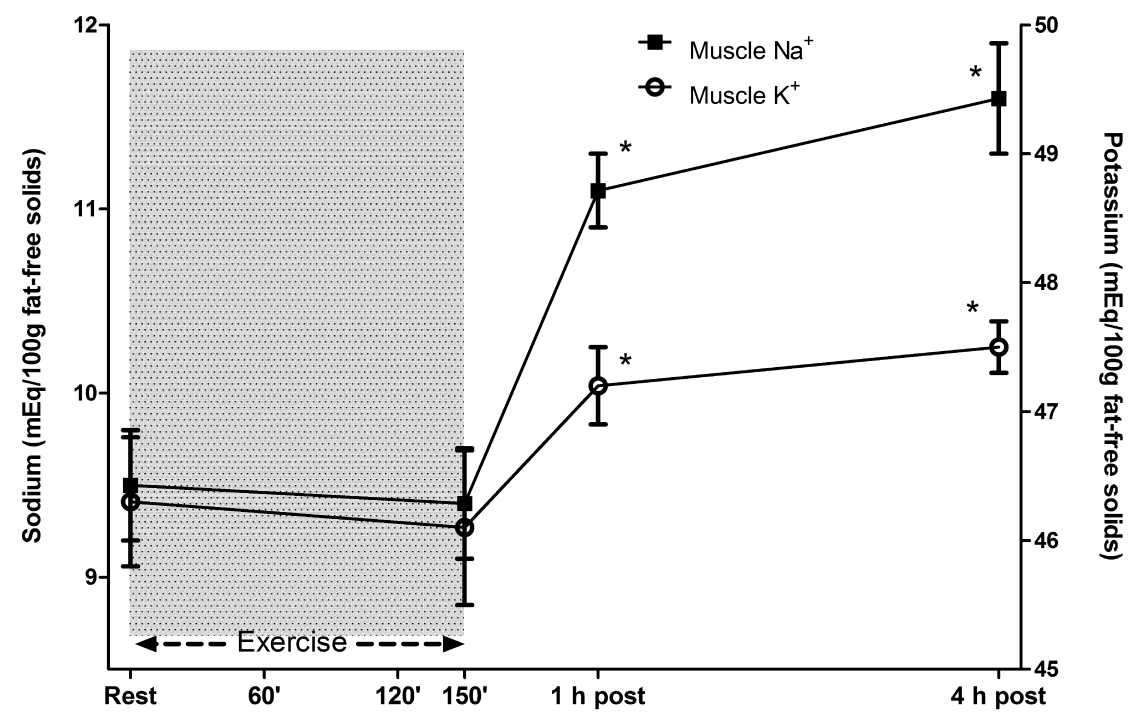

Fig. 2. Changes in muscle sodium and potassium during $150 \mathrm{~min}$ of dehydrating exercise and subsequent 4-h recovery. Data are means \pm standard error of the mean for nine endurance-trained subjects. *Significantly different from rest values $(P<0.05)$.

water from the legs $1 \mathrm{~h}$ after exercise (Table $2 ; P<0.05$ ). This loss was maintained after $4 \mathrm{~h}$ of exercise $(-0.476 \pm 0.10 \mathrm{~L} ; P<0.05)$.

\section{Changes in muscle and blood serum electrolytes}

Prior to exercise muscle $\mathrm{Na}^{+}$and $\mathrm{K}^{+}$were $9.5 \pm 0.3$ and $46.3 \pm 0.5 \mathrm{mEq} / 100 \mathrm{~g}$ of FFS, respectively. After exercise muscle $\mathrm{Na}^{+}$and $\mathrm{K}^{+}$remained at pre-exercise levels according to the lack of changes in $\mathrm{H}_{2} \mathrm{O}_{\text {muscle }}$. However, after 1 and $4 \mathrm{~h}$ of supine rest, values increased above basal values to $11.6 \pm 0.3$ and $47.5 \pm 0.2 \mathrm{mEq} /$ $100 \mathrm{~g}$ of FFS, respectively (Fig. $2 ; P<0.05$ ). These increases in muscle electrolytes coincided with the decreases in muscle water content. Changes from preexercise in concentration and contents of protein and electrolytes are depicted in Fig. 3. Serum $\mathrm{K}^{+}, \mathrm{Na}^{+}$, chloride $\left(\mathrm{Cl}^{-}\right)$, and total protein concentration increased during exercise $(32 \% \pm 4 \%, 4 \% \pm 1 \%, 6 \% \pm 1 \%$, $15 \% \pm 3 \%$, respectively; $P<0.05$ ). These increases in concentration were not due to increased contents as $\mathrm{Na}^{+}$, $\mathrm{Cl}^{-}$, and total protein contents were reduced. This was not the case with serum $\mathrm{K}^{+}$content that increased during exercise $(10 \% \pm 2 \% ; P<0.05)$. During the recovery after exercise, serum concentrations of electrolytes and protein declined while the contents returned to preexercise levels. Plasma protein contents actually increased during recovery above its pre-exercise levels $(9 \% \pm 2 \%)$.

\section{Body fluid shift}

During dehydrating exercise PV declined and as a consequence plasma $\mathrm{Cl}^{-}$increased (Table 3; $P<0.05$ ). Average sweat chloride concentration ranged from 51 to $55 \mathrm{mEq} / \mathrm{L}$ during exercise. Urine chloride concentration varied from 124 to $160 \mathrm{mEq} / \mathrm{L}$ as an average (Table 3). During exercise ECF declined to $-2.79 \pm 0.08 \mathrm{~L}$ $(P<0.05)$ while ICF increased from basal levels (Table 3). Lowering the work load during the last $30 \mathrm{~min}$ of exercise partly recovered ECF returning ICF to basal levels. One hour after exercise ECF returned to preexercise values (Table 3) while ICF was at the lower level. Four hours after exercise ECF and ICF remained at the levels observed after $1 \mathrm{~h}$ of exercise. 


\section{Mora-Rodríguez et al.}
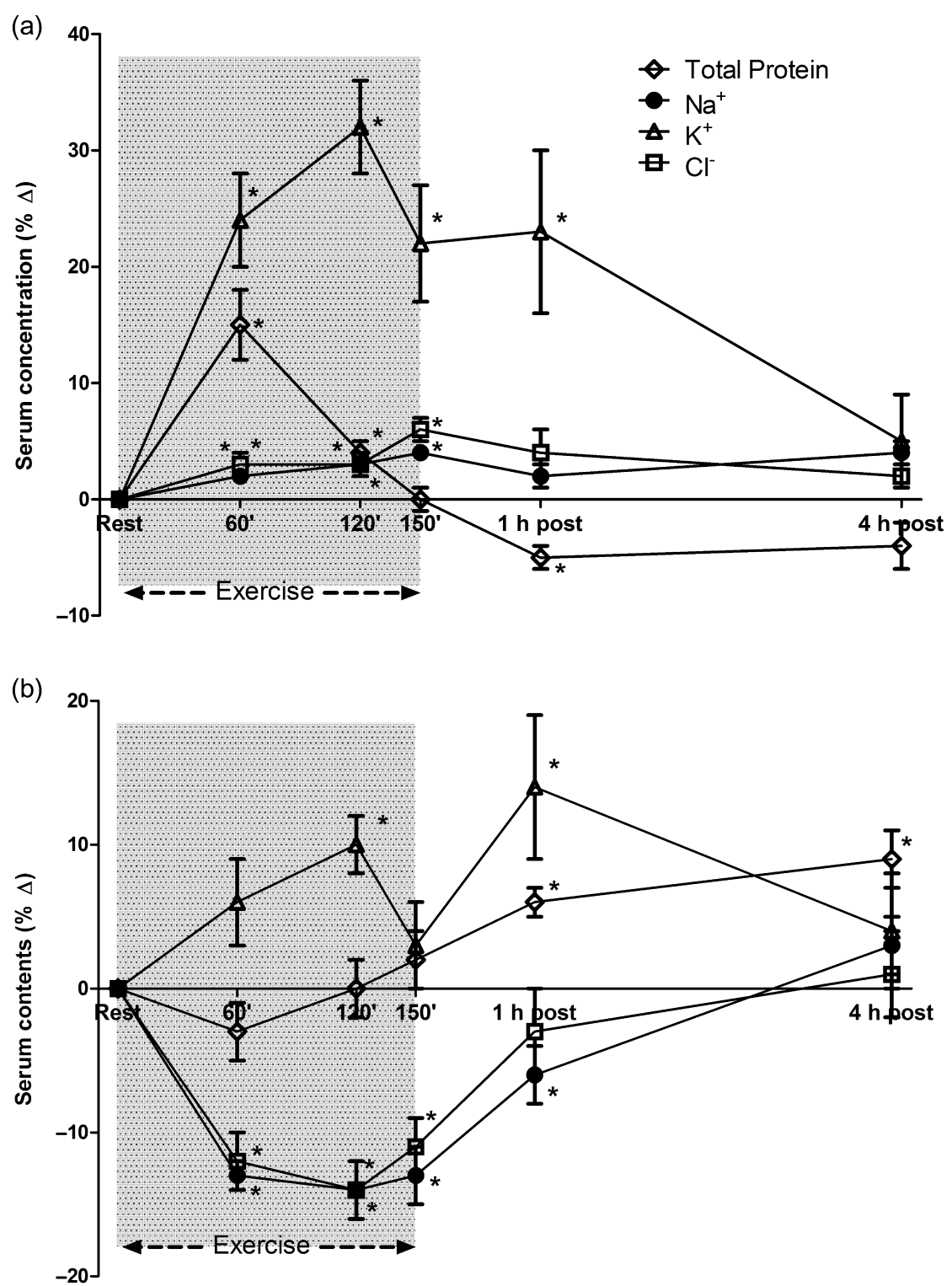

Fig. 3. Changes in plasma concentration (a) and contents (b) of protein, sodium, potassium, and chloride during 150 min of dehydrating exercise and subsequent 4 -h recovery. Data are means \pm standard error of the mean for nine endurance-trained subjects. *Significantly different from rest values $(P<0.05)$.

Table 3. Chloride concentration in serum, sweat, and urine prior, during, and after exercise and calculated extracellular (ECF) and intracellular fluid (ICF) following the chloride method

\begin{tabular}{lllcccc}
\hline & Rest & $60 \min$ & $120 \min$ & 150 min & Post 1h & Post 4 h \\
\hline $\mathrm{Cl}^{-}$serum blood (mEq/L) & $103 \pm 0.6$ & $106 \pm 0.6$ & $107 \pm 0.5$ & $109 \pm 0.4^{*}$ & $107 \pm 1.7$ & $105 \pm 0.9$ \\
$\mathrm{Cl}^{-}$sweat $(\mathrm{mEq} / \mathrm{L})$ & - & $51 \pm 3$ & $55 \pm 4$ & $51 \pm 3$ & - & - \\
$\mathrm{Cl}$ urine $(\mathrm{mEq} / \mathrm{L})$ & $124 \pm 16$ & - & - & - & $141 \pm 17$ & $160 \pm 9$ \\
ECF (L) & $0.0 \pm 0.0$ & $-2.2 \pm 0.8^{*}$ & $-2.8 \pm 0.8^{*}$ & $-1.6 \pm 0.6^{*}$ & $0.0 \pm 0.1$ & $0.0 \pm 0.2$ \\
ICF (L) & $0.0 \pm 0.0$ & $1.2 \pm 0.8$ & $0.5 \pm 0.8$ & $-1.8 \pm 0.5^{*}$ & $-3.4 \pm 0.2^{*}$ & $-2.9 \pm 0.3^{*}$ \\
\hline
\end{tabular}

Data are means \pm standard error of the mean for nine endurance-trained subjects.

*Significantly different from rest values.

\section{Discussion}

During prolonged exercise $(150 \mathrm{~min})$ in a hot environment $\left(33{ }^{\circ} \mathrm{C} ; 25 \% \pm 2 \%\right.$ humidity), body water is lost mainly through sweating (Table 1). In this situation, intravascular fluid (i.e., blood plasma) decreases due to its participation in sweat formation. However, the losses of PV (0.545 $\pm 0.05 \mathrm{~L}$; Fig. 1 and Table 2$)$ only explain $19 \%$ of all the fluid lost during exercise (Table 2). Thus, 
participation of interstitial and intracellular fluid on sweat formation for heat dissipation was initially hypothesized. Three decades ago, David Costill's group measured muscle water $\left(\mathrm{H}_{2} \mathrm{O}_{\text {muscle }}\right)$ changes after dehydrating exercise using muscle biopsies. Although in one study they showed a parallel reduction of $\mathrm{H}_{2} \mathrm{O}_{\text {muscle }}$ along with whole-body dehydration (Costill et al., 1976), they were not able to show reductions in $\mathrm{H}_{2} \mathrm{O}_{\text {muscle }}$ with similar dehydration in a subsequent study (Costill et al., 1981). Our data help to shed light into this apparent controversy. No net $\mathrm{H}_{2} \mathrm{O}_{\text {muscle }}$ loss was detected early after exercise (Costill et al., 1981) but after $1 \mathrm{~h}$ of supine rest a $13 \%$ reduction $\mathrm{H}_{2} \mathrm{O}_{\text {muscle }}$ appeared (Costill et al., 1976). Thus, a fluid equilibration time of $1 \mathrm{~h}$ is needed to measure the effects of whole-body dehydration on the previously active musculature.

We are not the first to report muscle water reductions induced by exercise in a hot environment. Using MRI technique, Hackney et al. (2012) reported a 1.2\% reduction in leg volume for each $1 \%$ decrease in body mass. Costill et al. (1976) also reported a similar ratio between losses of muscle water and whole-body weight. This ratio is interesting to define as it could allow predictions of muscle water losses by only measuring changes in body weight after exercise. However, the ratio between whole-body and muscle dehydration seems to depend on the intensity of exercise. Both investigators (Costill et al., 1976; Hackney et al., 2012) used very hot environments $\left(37-39^{\circ} \mathrm{C}\right)$ and low workload ( $97 \pm 39 \mathrm{~W}$; Hackney et al., 2012) to achieve up to $5 \%$ dehydration. In contrast, Neufer et al. (1991) using intense intermittent cycling and a warm environment reported an $8 \%$ reduction in active muscle water after $4.8 \%$ whole-body dehydration by exercise.

Our moderately intense pedaling produced a ratio between whole-body and muscle dehydration similar to Neufer's (i.e., $2.5 \%$ per each $1 \%$ loss of body weight). This suggests that exercise intensity influences the rate of muscle water loss in contracting skeletal muscle, with a higher rate indicating a higher workload. At low workloads, glycogenolysis rate is low (Horowitz et al., 1999) and less water may be liberated and available to be shifted away from the muscles. Prior studies (Costill et al., 1976; Neufer et al., 1991; Hackney et al., 2012) established that muscle water participates in the losses of fluid that take place during prolonged exercise in the heat. Our study helps to define the factors that influence the rate of muscle water loss during prolonged dehydrating exercise (e.g., exercise intensity). Furthermore, our study is unique in that it explores the connection between plasma and water muscle changes during the acute and prolonged phases of recovery (i.e., immediately, 1 and $4 \mathrm{~h}$ after exercise) after exercise.

During recovery from exercise, we observed that PV returned toward basal levels at the same time that $\mathrm{H}_{2} \mathrm{O}_{\text {muscle }}$ sharply declined 1-h post-exercise (Fig. 1). Our interpretation is that $\mathrm{H}_{2} \mathrm{O}_{\text {muscle }}$ reduction after exercise reflects the contribution of muscle fluid to the initial stages of PV recovery. Nose et al. (1988) have shown that two-thirds of $\mathrm{PV}$ are recovered $1 \mathrm{~h}$ after dehydrating exercise (2.3\% weight losses). We have recently shown (Hamouti et al., 2013) that, even if no rehydration is allowed, one-half of PV is recovered overnight after $3 \%$ dehydration is induced by exercise. At that time and based on indirect calculations (chloride method), we speculated that interstitial and intracellular water participated in the partial restoration of blood volume after exercise (Hamouti et al., 2013). Now, in addition to the indirect chloride method, we detected a post-exercise reduction in $\mathrm{H}_{2} \mathrm{O}_{\text {muscle }}$ coinciding with a recovery of $\mathrm{PV}$ (Fig. 1). Our data suggest that to restore PV after dehydrating, exercise water from previously active skeletal muscle is likely transferred to the vasculature. This restoration of PV helps to regain cardiovascular stability.

Using DXA regional analysis we assessed lower body soft-tissue mass. We extrapolated the water loss in the biopsy tissue after exercise to all the lower body soft-tissue mass measured in each individual (e.g., DXA; Table 2). To perform this calculation, we assumed that most leg lean soft tissue is muscle and that water was lost evenly throughout the leg musculature. We may have incurred into a slight overestimation as we chose to biopsy vastus lateralis which together with vastus medialis are the most heavily recruited muscles during cycling (Farina et al., 2004) and likely more prone to lose water (Hackney et al., 2012). Despite this overestimation, muscle and plasma water losses together could not account for the water lost during exercise as sweat, breath, and urinary water (Table 2). Thus, other tissues must have participated in body water losses. Data from Costill et al. (1981) indicate that inactive muscle groups (i.e., deltoids during cycling) do not loose water during dehydrating pedaling in the heat. Other candidate tissues to provide water for thermoregulation during prolonged exercise are the interstitial space, the skin, and the gastrointestinal system.

During exercise or immediately after exercise, something prevented $\mathrm{H}_{2} \mathrm{O}_{\text {muscle }}$ from mitigating PV reductions. During exercise the increased muscle perfusion pressure (i.e., blood pressure) forces plasma into the interstitial space of active muscle (Friedman et al., 1982). In addition, the increased metabolite concentration during muscle contraction raises osmotic forces that draw fluid out of the plasma into the muscle (Lundvall, 1972). However, upon exercise discontinuation, blood pressure drops back to resting values or lower (Senay et al., 1980) allowing fluid to be reincorporated into plasma. In addition, during recovery, the metabolites accumulated during exercise are gradually removed or oxidized and osmotic forces re-equilibrate between blood and muscle. Still, right after exercise, $\mathrm{H}_{2} \mathrm{O}_{\text {muscle }}$ content did not drop below basal levels. It is possible that during exercise $\mathrm{H}_{2} \mathrm{O}_{\text {muscle }}$ increased above basal levels, and that there was an actual drop of $\mathrm{H}_{2} \mathrm{O}_{\text {muscle }}$ returning to pre-exercise levels, explaining the lack of net changes at the end of prolonged exercise. Short-term intense exercise increases active 


\section{Mora-Rodríguez et al.}

muscle water content (Sjøgaard \& Saltin, 1982; PloutzSnyder et al., 1995; Kristiansen et al., 2014). However, it is unclear if that acute increase in exercising muscle water is maintained during prolonged dehydrating exercise.

There are alternative explanations for the lack of $\mathrm{H}_{2} \mathrm{O}_{\text {muscle }}$ loss right after exercise. Costill (1977) speculated that the unchanged $\mathrm{H}_{2} \mathrm{O}_{\text {muscle }}$ after exercise may be due to the compensatory role of water formation during oxidation and/or from water liberated from glycogen. These sources of water could have matched the $\mathrm{H}_{2} \mathrm{O}_{\text {muscle }}$ lost resulting in unchanged levels after exercise. Substrate oxidation was calculated based on non-protein respiratory exchange ratio, and water from oxidizing fat and carbohydrates was based on Maughan et al.'s (2007) publication. Water from oxidation mounted to $0.27 \pm 0.01 \mathrm{~L}$ that could have been produced during the $150 \mathrm{~min}$ of exercise (Table 1). Although the amount of water bound to glycogen that is liberated during exercise is unknown (Sherman et al., 1982), based on associations between water and glycogen storage after exercise (Olsson \& Saltin, 1970), a ratio of 3 to 1 has been proposed. Based on a previous study (Horowitz et al., 1999), we calculated an average glycogen use of $1.8 \mathrm{~g} / \mathrm{min}$ during the exercise intensity held in our trial. Thus, $0.81 \mathrm{~L}$ of water bound to glycogen could have been liberated in the exercising muscle in our study. Even taking into account these sources of water formation, it is possible that active leg muscles had contributed up to $1.1 \mathrm{~L}$ of the sweat losses, without incurring in any measurable $\mathrm{H}_{2} \mathrm{O}_{\text {muscle }}$ net deficit. Further studies with metabolic tracing of water may confirm or correct this prediction.

Our data suggest that muscle participates in the recovery of PV although it may be a limitation to the water that can be lost from muscle. This is evidenced by the lack of loss in $\mathrm{H}_{2} \mathrm{O}_{\text {muscle }}$ from 1 to $4 \mathrm{~h}$ of recovery despite progressive PV recovery during this time. Also, body fluid shift calculations corroborated biopsy measurements in that no recovery of ICF was present in the $4 \mathrm{~h}$ of supine post-exercise. It is possible that osmotic forces may have re-equilibrated between plasma and muscle $1 \mathrm{~h}$ after exercise. This may have halted the driving force for fluid exchange between these two compartments. Corroborating this osmotic equilibration, we reported that muscle electrolytes $\left(\mathrm{Na}^{+}\right.$and $\left.\mathrm{K}^{+}\right)$remained at high levels from 1 to $4 \mathrm{~h}$ after exercise (Fig. 2). Despite the unchanged $\mathrm{H}_{2} \mathrm{O}_{\text {muscle }}$, $\mathrm{PV}$ kept recovering during the last $3 \mathrm{~h}$ of the 4-h post-exercise recovery period, which indicated that other tissues apart from muscle participated in $\mathrm{PV}$ restoration. Thus, although an important contributor, $\mathrm{H}_{2} \mathrm{O}_{\text {muscle }}$ is not the only fluid involved in the restoration of PV after exercise. Other fluid compartments (i.e., interstitial) are likely involved in this response.

The redistribution of water across the muscle cell membrane during dehydration is dependent on the osmotic gradient and the activity of the ionic pumps (Sawka, 1992). Osmotic forces that draw fluid into plasma are primarily determined by serum proteins (oncotic pressure) and electrolytes. However, measuring the concentration of these metabolites do not fully inform of the fluid shift but rather the end result of those shifts. To gain insight into the nature of the fluid shift during and after prolonged dehydrating exercise, we calculated plasma contents of protein and electrolytes (Fig. 3). During exercise, total protein concentration was increased while protein content decreased. This indicates that total protein concentration was primarily a result of the loss of fluid from plasma. However, after exercise, total protein concentration declined while content in plasma increased. Influx of protein into plasma during recovery has been previously reported (Senay et al., 1980; Gillen et al., 1991). During exercise, plasma contents of $\mathrm{Na}^{+}$and $\mathrm{Cl}^{-}$decreased due to their excretion in sweat, while their concentration increased (van Beaumont et al., 1973) due to the hypotonic nature of sweat inducing larger losses of plasma than electrolytes. However, plasma $\mathrm{K}^{+}$content increased during exercise likely from muscle sources (Kilburn, 1966). In summary, the increase in plasma $\mathrm{Na}^{+}, \mathrm{Cl}^{-}$, and protein concentration with exercise are the results of hemoconcentration and not induced by a release of proteins from extravascular sources. The hemodilution observed during recovery from prolonged dehydrating exercise occurs despite release of proteins and electrolytes into the plasma.

In summary, we found that (a) right after exercise muscle $\mathrm{H}_{2} \mathrm{O}$ is not reduced from pre-exercise values suggesting that either muscle does not contribute to water for thermoregulation (i.e., sweat) or that water is formed (metabolic or glycogen bound) at the same rate that it is lost from the muscle; (b) however, $1 \mathrm{~h}$ after exercise $\mathrm{H}_{2} \mathrm{O}_{\text {muscle }}$ declines likely to restore PV; and (c) finally, $4 \mathrm{~h}$ after exercise PV keeps recovering without apparent contribution from muscle $\mathrm{H}_{2} \mathrm{O}$. Our data suggest that muscle water contributes to the first stages of PV recovery after prolonged dehydrating exercise. However, this contribution is not evident right after exercise and requires $60 \mathrm{~min}$ of supine rest to emerge.

\section{Perspectives}

Insufficient fluid replacement during physical activities that entail profuse sweating results in whole-body fluid deficit. However, how that deficit is shared by the different bodily fluid compartments is unclear, however relevant. Water has important metabolic roles in human skeletal muscle and its deficit may delay the recovery of muscle energy substrates and the elimination of built-up metabolites, and could even stimulate catabolism in muscle (Häussinger, 1996). Our data show that after large whole-body dehydration $(4.7 \%)$ plasma fluid is fully recovered at the expense of fluid from skeletal muscle during the first hour of recovery (Fig. 1). In this study, we describe the magnitude and timing of this muscle water deficit after exercise. The metabolic consequences of this post-exercise skeletal muscle dehydration are still to be described. 


\section{Fluid losses in exercising skeletal muscle}

Key words: Exercise, plasma volume, body water, water loss, intracellular fluid, extracellular fluid.

\section{Acknowledgements}

We thank the help and collaboration of Dr. Jacinto Alonso Azcarate, Dr. Patricia Ruiz Perez, and Fatima Perez Martin from the Faculty of Environmental Sciences and Biochemistry at the University of Castilla-La Mancha. We also acknowledge the dedication of each of the nine cyclists who participated in this study. This study was partially funded with a grant from the Spanish Ministry of Educacion y Ciencia (DEP2006-56076-C06-02). V. E. F.-E. was supported by a predoctoral fellowship from the Junta de Comunidades de Castilla-La Mancha.

\section{References}

Costill DL. Sweating: its composition and effects on body fluids. Ann N Y Acad Sci 1977: 301: 160-174.

Costill DL, Coté R, Fink W. Muscle water and electrolytes following varied levels of dehydration in man. J Appl Physiol 1976: 40: 6-11.

Costill DL, Coté R, Fink WJ, Van Handel $P$. Muscle water and electrolyte distribution during prolonged exercise. Int J Sports Med 1981: 2: 130-134.

Costill DL, Pearson DR, Fink WJ. Impaired muscle glycogen storage after muscle biopsy. J Appl Physiol 1988: 64: 2245-2248.

Dill DB, Costill DL. Calculation of percentage changes in volumes of blood, plasma, and red cells in dehydration. J Appl Physiol 1974: 37: 247-248.

Farina D, Macaluso A, Ferguson R, De Vito G. Effect of power, pedal rate, and force on average muscle fiber conduction velocity during cycling. J Appl Physiol 2004: 97: 2035-2041.

Friedman JJ, Szwed JJ, Johns BL. Mass-balance approach for estimating transcapillary fluid and protein movement. Am J Physiol 1982: 242: H227-H232.

Gillen CM, Lee R, Mack GW, Tomaselli CM, Nishiyasu T, Nadel ER. Plasma volume expansion in humans after a single intense exercise protocol. J Appl Physiol 1991: 71: 1914-1920.

Hackney KJ, Cook SB, Fairchild TJ, Ploutz-Snyder LL. Skeletal muscle volume following dehydration induced by exercise in heat. Extrem Physiol Med 2012: 1: 3.

Hamouti N, Del Coso J, Mora-Rodriguez R. Comparison between blood and urinary fluid balance indices during dehydrating exercise and the subsequent hypohydration when fluid is not restored. Eur J Appl Physiol 2013: 113: 611-620.

Hamouti N, Del Coso J, Ortega JF, Mora-Rodriguez R. Sweat sodium concentration during exercise in the heat in aerobically trained and untrained humans. Eur J Appl Physiol 2011: 111: 2873-2881.

Häussinger D. The role of cellular hydration in the regulation of cell function. Biochem J 1996: 1: 697-710.

Horowitz JF, Mora-Rodriguez R, Byerley LO, Coyle EF. Substrate metabolism when subjects are fed carbohydrate during exercise. Am J Physiol 1999: 276: E828-E835.

Jeukendrup AE, Wallis GA. Measurement of substrate oxidation during exercise by means of gas exchange measurements. Int J Sports Med 2005: 26: S28-S37.

Kilburn KH. Muscular origin of elevated plasma potassium during exercise. $\mathrm{J}$ Appl Physiol 1966: 21: 675-678.

Kristiansen MS, Uhrbrand A, Hansen M, Shiguetomi-Medina JM, Vissing K, Stodkilde-Jorgensen H, Langberg H. Concomitant changes in cross-sectional area and water content in skeletal muscle after resistance exercise. Scand J Med Sci Sports 2014: 24: e260-e268.

Lundvall J. Tissue hyperosmolality as a mediator of vasodilatation and transcapillary fluid flux in exercising skeletal muscle. Acta Physiol Scand 1972: 379 (Suppl.): 1-142.

Maughan RJ, Shirreffs SM, Leiper JB. Errors in the estimation of hydration status from changes in body mass. J Sports Sci 2007: 25: 797-804.

Mitchell JW, Nadel ER, Stolwijk JA. Respiratory weight losses during exercise. J Appl Physiol 1972: 32: 474-476.

Neufer PD, Sawka MN, Young AJ, Quigley MD, Latzka WA, Levine L. Hypohydration does not impair skeletal muscle glycogen resynthesis after exercise. J Appl Physiol 1991: 70: 1490-1494.

Nose H, Mack GW, Shi XR, Nadel ER. Shift in body fluid compartments after dehydration in humans. J Appl Physiol 1988: 65: 318-324.

Olsson KE, Saltin B. Variation in total body water with muscle glycogen changes in man. Acta Physiol Scand 1970: 80: 11-18.

Patterson MJ, Galloway SD, Nimmo MA. Variations in regional sweat composition in normal human males. Exp Physiol 2000: 85: 869-875.

Ploutz-Snyder LL, Convertino VA, Dudley GA. Resistance exerciseinduced fluid shifts: change in active muscle size and plasma volume. Am J Physiol 1995: 269: R536-R543.

Sanders B, Noakes TD, Dennis SC. Water and electrolyte shifts with partial fluid replacement during exercise. Eur J Appl Physiol Occup Physiol 1999: 80: 318-323.

Sanders B, Noakes TD, Dennis SC. Sodium replacement and fluid shifts during prolonged exercise in humans. Eur J Appl Physiol 2001: 84: 419-425.

Sawka MN. Physiological consequences of hypohydration: exercise performance and thermoregulation. Med Sci Sports Exerc 1992: 24: 657-670.

Sawka MN, Burke LM, Eichner ER, Maughan RJ, Montain SJ, Stachenfeld NS. American College of Sports Medicine position stand. Exercise and fluid replacement. Med Sci Sports Exerc 2007: 39: 377-390.

Sawka MN, Young AJ, Pandolf KB, Dennis RC, Valeri CR. Erythrocyte, plasma and blood volume of healthy young men. Med Sci Sports Exerc 1992: 24: 447-453.

Schäfer C, Gehrmann T, Richter L, Keitel V, Köhrer K, Häussinger D, Schliess F. Modulation of gene expression profiles by hyperosmolarity and insulin. Cell Physiol Biochem 2007: 20: 369-386.

Senay LCJ, Rogers G, Jooste P. Changes in blood plasma during progressive treadmill and cycle exercise. J Appl Physiol 1980: 49: 59-65.

Sherman WM, Plyley MJ, Sharp RL, Van Handel PJ, McAllister RM, Fink WJ, Costill DL. Muscle glycogen storage and its relationship with water. Int J Sports Med 1982: 3: 22-24.

Sjøgaard G, Adams RP, Saltin B. Water and ion shifts in skeletal muscle of humans with intense dynamic knee extension. Am J Physiol 1985: 248: R190-R196.

Sjøgaard G, Saltin B. Extra- and intracellular water spaces in muscles of man at rest and with dynamic exercise. Am J Physiol 1982: 243: R271-R280.

Tarnopolsky MA, Pearce E, Smith K, Lach B. Suction-modified Bergstrom muscle biopsy technique: experience with 13,500 procedures. Muscle Nerve 2011: 43: 717-725.

van Beaumont W, Strand JC, Petrofsky JS, Hipskind SG, Greenleaf JE. Changes in total plasma content of electrolytes and proteins with maximal exercise. J Appl Physiol 1973: 34: 102-106. 